\title{
R-learning with Multiple State-action Value Tables
}

\author{
Koichiro Ishikawa Non-member (Japan Advanced Institute of Science and Technology, koichiro@jaist.ac.jp) \\ Akito Sakurai Member (Keio University, sakurai@ae.keio.ac.jp) \\ Tsutomu Fujinami Non-member (Japan Advanced Institute of Science and Technology, fuji@jaist.ac.jp) \\ Susumu Kunifuji Non-member (Japan Advanced Institute of Science and Technology, kuni@jaist.ac.jp)
}

Keywords: reinforcement learning, R-learning, autonomous mobile robot

We propose a method to improve the performance of Rlearning, a reinforcement learning algorithm, by using multiple state-action value tables. Unlike Q- or Sarsa learning, R-learning learns a policy to maximize undiscounted condition.

It was reported that learning speed of R-learning was faster than that of Q-learning and, on the other hand, it tends to result in suboptimal local solution. This weakness could be eased by intensifying exploration that, however, may decrease total reward. Multiple state-action value tables cause substantial explorations as needed and make R-learnings to work well.

Fig. 1 shows the procedure of the proposed method. Our system uses multiple state-action tables $\left(R_{m}\right)$ each of which uses different sensor set $(m)$ for deciding robot actions and learning adequate actions (line 2-3). One of the state-action table is selected, according to its preference (line 8-11), and decides robot action finally (line 13-21). Prefernces (line 27),

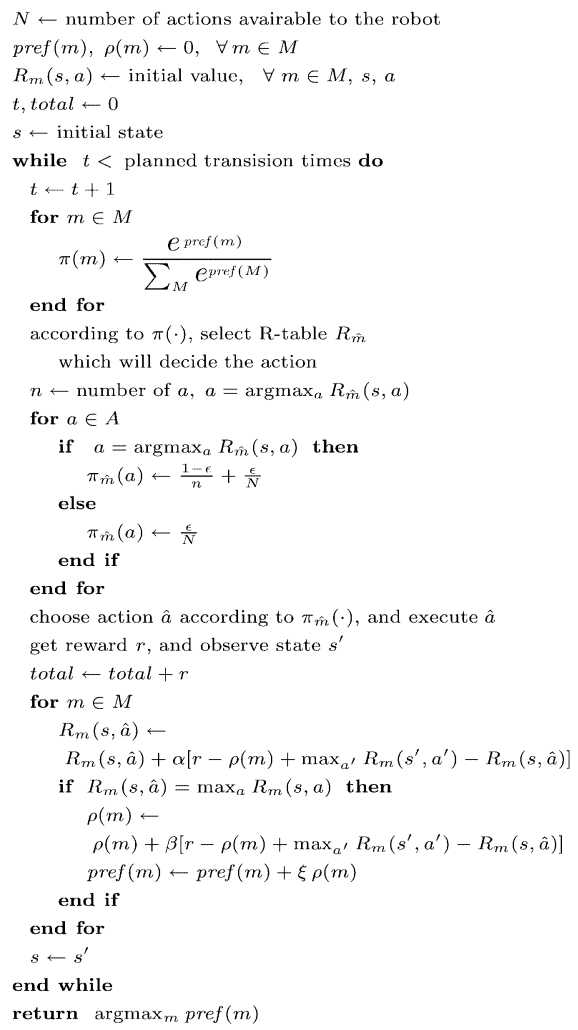

Fig. 1. Procedure of the proposed method.
$\mathrm{R}$ values (line 23-24), and $\rho$ (estimated average reward) are updated according to reward.

Proposed method is applied to mobile robot navigation task and evaluated through experiments on a Khepera robot simulator. The robot in the simulation emvironment, with no prior knowledge, learns how to act avioding collisions with walls.

Khepera robot has eight sensors equiped along its body. As $R_{m}$ mentioned above, we limited only 21 state-action tables out of $255\left(=2^{8}-1\right)$ possible tables, one table which uses all equiped sensors and 20 randomly selected tables each of which uses less than three sensors.

Results of the experiments reveal that our approach works well to reduce learning time. In terms of average reward, proposed method outperforms other methods as shown in Fig. 2 and Table 1.

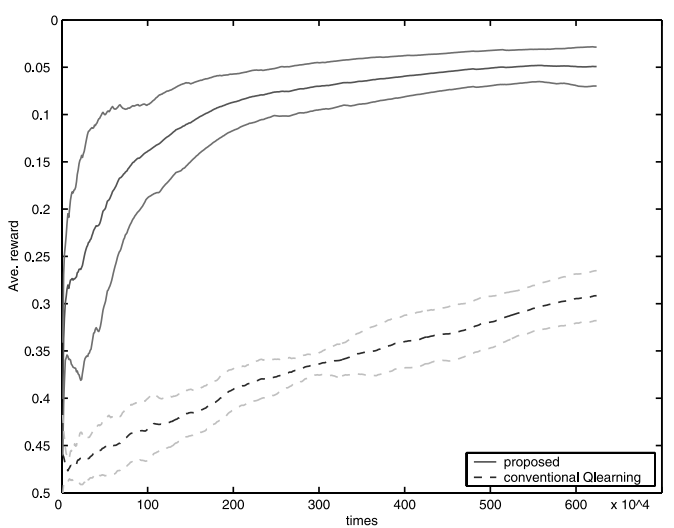

Fig. 2. Average rewards of proposed method versus conventional Q-learning.

Table 1. Summarized result of expriments: average reward of proposed method versus others.

\begin{tabular}{|l|l|c|l|}
\hline $\begin{array}{c}\text { learning } \\
\text { method }\end{array}$ & $\begin{array}{c}\text { exploration } \\
\text { method }\end{array}$ & $\begin{array}{c}\text { average } \\
\text { reward }\end{array}$ & \\
\hline $\mathrm{R}$ & proposed & -0.0492 & mean of 10 experiments \\
\cline { 2 - 4 } & $\epsilon$-greedy & -0.4945 & mean of 10 experiments \\
\cline { 2 - 4 } & UE & -0.3393 & mean of 5 experiments \\
\cline { 2 - 4 } & softmax & -0.3235 & mean of 5 experiments \\
\hline $\mathrm{R}+\mathrm{CMAC}$ & $\epsilon$-greedy & -0.3980 & mean of 5 experiments \\
\hline $\mathrm{Q}$ & $\epsilon$-greedy & -0.2915 & mean of 10 experiments \\
\hline $\mathrm{Q}+\mathrm{CMAC}$ & $\epsilon$-greedy & -0.1429 & mean of 5 experiments \\
\hline Sarsa & $\epsilon$-greedy & -0.2964 & mean of 10 experiments \\
\hline
\end{tabular}




\title{
複数の状態行動価值表を用いた R 学習の高速化
}

\author{
非会員 石川 浩一郎* 正 員 櫻井 彰人** \\ 非会員 藤波努* 非会員 國藤 進*
}

\author{
R-learning with Multiple State-action Value Tables \\ Koichiro Ishikawa*, Non-member, Akito Sakurai**, Member, \\ Tsutomu Fujinami*, Non-member, Susumu Kunifuji*, Non-member
}

\begin{abstract}
We propose a method to improve the performance of R-learning, a reinforcement learning algorithm, by using multiple state-action value tables. Unlike Q- or Sarsa learning, R-learning learns a policy to maximize undiscounted rewards. Multiple state-action value tables cause substantial explorations as needed and make R-learnings to work well. Efficiency of the proposed method is verified through experiments in simulation environment.
\end{abstract}

キーワード : 強化学習, $\mathrm{R}$ 学習, 自律移動型ロボット

Keywords: reinforcement learning, R-learning, autonomous mobile robot

\section{1. 緒 論}

強化学習とは, 正しい行動出力を明示的に示す教師情報 の代わりに, 報酬と呼ばれるスカラの情報を手がかりとし, 試行錯誤によって環境に応じた最適な行動方策を学習する 方法である(1)。強化学習における最終目的は, マルコフ決 定過程 (Markov decision process; MDP) における累積報 酬の最大化と定式化されるが，無限に動作を継続する場合 (infinite horizon), 累積報酬は一般に有界でないため, 通 常, 将来の獲得報酬を割引くか, 1 行動当たりの平均報酬 を考える。

例えば，Q 学習は前者の例であり，1行動毎一定の率で割 引いた累積報酬を最大化する方策を，学習によって獲得さ せることを目的としている。一方 $\mathrm{R}$ 学習は, 平均報酬の最 大化を目指す学習手法であり，Q 学習のように model-free かつ asynchronous な更新を行うことを特徵とする ${ }^{(2)}$ 。

$\mathrm{R}$ 学習は，Q 学習より早く収束するといわれているが, その反面, 局所解に陥り易いという久点も指摘されてい

\footnotetext{
* 北陸先端科学技術大学院大学 知識科学研究科

干 923-1292 石川県能見市旭台 1-1

School of Knowledge Science,

Japan Advanced Institute of Science and Technology

1-1, Asahi-dai, Nomi 923-1292

** 慶應義塾大学 理工学部 管理工学科

干 223-8522 神奈川県横浜市港北区日吉 3-14-1

Department of Administration Engineering,

Faculty of Science and Technology, Keio University

3-14-1 Hiyoshi, Kouhoku-ku, Yokohama, 890-0099

科学技術振興機構 戦略的創造研究推進事業
}

る (3) (4)。ここで局所解とは, グリーディ方策に従うと最適 でない行動をとることになり, かつそれ以上の学習が困難 な状態行動価值†関数またはその集合を指す。

本論文では, 複数の状態行動価值 (表) を用いる R 学習 手法を提案する。本手法の適用で探索が促進され，局所解 からの脱出が早まる結果, 迅速な学習が実現される (本論 文では, 環境との相互作用回数の減少を, 学習速度の向上 ととらえるものとする)。

手法の評価に当たっては, 自律型移動ロボットの障害物 回避行動の獲得課題を用いた。実験では, 複数の異なるセ ンサの組合せ (本論文ではセンサ集合と呼ぶ) 1 つに対して $1 つ の \mathrm{R}$ 学習を割り当てて, 同時並行的に学習させた。シ ミュレーション実験では, 提案手法は, $\mathrm{R}$ 学習の欠点であ る局所解への陥りを解消し, 通常の Q 及び Sarsa 学習よ り,さらには CMAC 手法を適用した強化学習より性能が 良いことを確認した。

以下，本論文の構成を示す。 2 . にて, $\mathrm{R}$ 学習手法の処理 とその問題点を述べた後, 3. で, 提案手法について, その アイデア，期待効果，具体的な処理の順に記述する。4. で は, 簡単な設定の実験により, 提案手法の適用で学習内容 の優れた状態行動価值表が優先的に利用され, 学習が高速 化されることを確認する。5.では, より現実的な設定の実 験で, 提案手法が他の諸手法より優れた平均獲得報酬を実 現可能であることを示す。6. で, 各実験の結果について考

†行動価值とも呼ばれるが，本論文では状態依存であることを明示 するため状態行動価值というものとする。 
察した後，7. で全体をまとめる。

\section{2. $\mathbf{R}$ 学習と局所解}

$\langle\mathbf{2} \cdot \mathbf{1}\rangle \mathbf{R}$ 学 習 $\mathrm{R}$ 学習は, Schwartz が提案した, 割引が行われない強化学習課題を扱うための手法で, 単位 時間ステップ当たりの平均報酬 $(\rho)$ の最大化を目標とする 点が, $\mathrm{Q}$ 学習と異なる特徴となっている( ${ }^{(5)}$ 。

off-policy 型の R 学習における, 状態行動対の価值の推 定の改善は，次式によって行われる。

$$
\begin{aligned}
& R(s, a) \leftarrow \\
& \quad R(s, a)+\alpha\left[r-\rho+\max _{a^{\prime}} R\left(s^{\prime}, a^{\prime}\right)-R(s, a)\right]
\end{aligned}
$$

また，実際にとった行動が探索行動でなかった際のみ $\rho$ の更新が行われ，更新式は次式の通りである。

$$
\rho \leftarrow \rho+\beta\left[r-\rho+\max _{a^{\prime}} R\left(s^{\prime}, a^{\prime}\right)-R(s, a)\right]
$$

ここで, $s$ は現在の状態， $a$ は採用した行動， $s^{\prime}$ は行動後の 新しい状態， $a^{\prime}$ は新しい状態において選択される行動であ る。また, $r$ は行動によって得られた報酬を示す。本論文の 実験では，一部負の報酬を用いた $(\langle 5 \cdot 1 \cdot 2\rangle$ 参照 $)$ 。 $R(s, a)$ は, 状態 $s$ において行動 $a$ を選択した場合の状態行動価値 推定を示し， $\alpha$ 及び $\beta$ は学習率と呼ばれる係数である。な お, $\mathrm{R}$ 学習は, 現時点で, 学習の収束性が理論的に証明さ れていない。

$\langle 2 \cdot 2\rangle \quad R$ 学習における局所解 $\mathrm{R}$ 学習では, 探索方 法を適宜選ばないと，行動が容易に limit cycle 状況に陥り， 学習が十分進まなくなることがあると指摘されている ${ }^{(3)}$ 。 ここで, limit cycle 状況とは, $r-\rho$ が 0 となり, 交互に訪 問される $2 つ の$ 状態の状態行動価值が変化しなくなること を指す。これは, 局所解の特別な場合と考えられる。Mahadevanはロボットの箱押し課題を取り上げ, limit cycle 状況に陥った結果, $\mathrm{R}$ 学習の成績が $\mathrm{Q}$ 学習に劣り, とくに 行動選択手法に softmax 手法(5)を用いた場合に性能の差 が著しいと報告している。

Mahadevan が実験に使用し, limit cycle 状況に陥るこ とを回避する効果を認めた探索方法は， $\epsilon$-greedy または UE (uncertainty estimation)である(4)。しかし，例えば 我々の実験では, $\langle 5 \cdot 2 \cdot 2\rangle,\langle 5 \cdot 2 \cdot 3\rangle$ に述べるように，両手法 とも十分な成績は得られなかった(この点に関する分析は 6 . 参照)。この際, 多数の状態 (例えば 32 状態) を遍歴するこ と, 及び状態行動価值に差が見られることから, Mahadevan のいう limit cycle 状況より一般的な局所解に陥った と考えられる。また, 局所解の脱出には探索的行動を増や すことが有効であるとされているが，単純に探索を増やす ことは, 学習過程の遅れや, それまでの獲得内容の破壊に つながることは, 容易に推測される (本論文では, こうし た副作用を擾乱と呼ぶものとする)。

\section{3. 提案手法}

2.で記述した問題への対応策の 1 つして，本論文では， 状態空間分割が互いに異なる複数の強化学習 (以下それぞれ を学習器と呼ぶ）を同時に実行する手法を採用した。以下 の説明及び 4 . 以下の実験では, 複数のセンサをもつロボッ 卜を想定している。しかし，次節で述べるように，本手法 は通常の強化学習課題に, 広く適用可能である。

$\langle\mathbf{3 \cdot 1}\rangle$ 複数の状態空間分割 強化学習は, エージェント とそれが相互作用する環境とを用いて定式化される(5)。エー ジェントと環境は離散的な時間ステップ $t=0,1,2,3, \ldots$ の各々に扔いて相互作用を行い, その関係・状態が変化す る。各時間ステップにおいて, エージェントとその環境は, ある状態 $s_{t} \in S(S$ は可能な状態の集合) にある。エー ジェントは, 状態のある表現を受取り, それを記述し, 得 た状態記述 $D\left(s_{t}\right)$ に基づいて行動 $a_{t} \in A\left(s_{t}\right)$ を選択する $\left(A\left(s_{t}\right)\right.$ は状態 $s_{t}$ において選択することのできる行動の集 合である)。なお, 式 (1), (2) では, 状態の表現 $D(s)$ を状 態 $s$ で表している。

状態の記述には様々な可能性がある。例えば, 状態 $s$ に扔いてエージェントが $n$ 個のセンサを用いて得る情 報を $s_{1}, \ldots, s_{n}$ とする。このとき $n$ 個組 $D_{0}(s)=<$ $s_{1}, s_{2}, \ldots, s_{n}>$ は一つの状態記述である。得られる情報の 一部を用いた記述 $D_{i}, i \in I(I$ は得られる情報の全ての組 合せで，全情報を用いるものは含まない）も状態記述であ る。 $D_{0}$ を用いると異なる状態記述となる状態が, $D_{i}(i \in I)$ を用いると同じ記述になることがあるが，その逆はない。 すなわち, $D_{i}(i \in I)$ の方が $D_{0}$ より粗い記述である。

提案手法では，用いる情報を変えた粗い記述を複数用意 し, それらの各々を利用する学習器と, 全ての情報を用い た記述 $D_{0}$ を利用する学習器とを併せて, 多数の学習器を 同時並行的に動作させ, 学習と行動決定を進める。

なお，複数の状態空間分割を実現する方法としては，上述 のように粗い状態記述を用いる方法の他, 入力情報を離散化 する過程でのオフセットによる方法も考えられる $(\langle 5 \cdot 2 \cdot 6\rangle$ 参照)。すなわち, CMAC 手法におけるタイリングも, 以 上の 2 つの方法を用いて, 複数の状態分割を実現している と考えられる。以降の説明及び実験では, 粗い記述を用い て複数の状態空間分割を実現する方法のみを採用したが， オフセットを用いる方法も学習上有効である可能性はある。 また，提案手法は，上記以外の方法で複数個の学習器を実 現した場合にも適用可能であるが，本論文では，こうした 条件下での有効性の検証は行っていない。

提案手法では, 以上で述べた複数の学習器のうち, 優秀 と推測されるものを選択し, 行動を決定する。選択は, 各 $\mathrm{R}$ 值表の $\rho$ 值, 寸なわち平均報酬の期待值に基づく確率分 布を用いてランダムに行う。この結果, 学習結果に差が出 る状況では, 最適行動列を早く学習できた (すなわち $\rho$ 值 が早く増加した) R 值表が優先して用いられ，また局所解 状況では, 複数個の $\mathrm{R}$ 值表が用いられる傾向が強まると考 
えられ，次節のような効果が期待できる。

$\langle\mathbf{3 \cdot 2 \rangle}$ 期待効果 複数の強化学習を並行的に用いるこ とで高速な学習が実現可能である。第 1 の理由として, 局 所解にとらわれた場合， $\epsilon$-greedyによる探索のような単純 な blind search の繰り返しとは異なる探索を行う可能性が あるからである。これは，局所解にとらわれていない学習 器が存在したり, または局所解にとらわれていても別の行 動列を生成する学習器が存在する可能性があり, このよう な場合, 局所解にとらわれている学習器は, 相対的な $\rho$ 值 の低下により選択されなくなるからである。

第 2 の理由は，グリーデイな行動以外の行動の結果，あ る学習器に擾乱が発生しても, 他の学習器がそれを代替す る可能性があるからである。擾乱により当該学習器が不適 切な行動を繰り返した場合，他にそれまでの学習内容を保 持している学習器があれば, 後者が選択されるようになり, もとの学習内容の復旧に要する時間も短縮される可能性が ある。

第 3 の理由として，局所解にとらわれることがない場合 は，従来法に比較して少なくとも遜色のない速度で学習で きると予想されることである。この場合, どの学習器も学 習が早くすすみ, その中でも $\rho$ 值が早く立ち上がる学習器 が選択され，したがって $\mathrm{R}$ 值表を 1 つしか用いない従来の $\mathrm{R}$ 学習を適用する場合と比較して, 遜色ない速度で学習が 進むことが期待されるからである。

$\langle\mathbf{3} \cdot 3\rangle$ 処 理 手法の具体的処理を図 1 に示す。利 用するセンサ集合が異なる複数の $\mathrm{R}$ 值表を用意する。各 $\mathrm{R}$ 值表で利用するセンサ集合を $m$ と考える。 $\mathrm{R}$ 值表 $R_{m}$ の優 先度を pref $(m)$ とする (行 2 )。この優先度に, softmax 手 法 (5) を適用して行動を決定する R 值表を選択し (行 8-11), $\epsilon$-greedy 手法 ${ }^{(5)}$ でロボットが実際にとる行動を決定する (行 13-20)。行動後, 各 R 值表を更新するが, 更新式は通 常の off-policy 型 R 学習と同一である (行 23-26, 28)。さ らに，ロボットが実際にとった行動が，各 $\mathrm{R}$ 值表で $\mathrm{R}$ 值最 大であった場合のみ，この $\mathrm{R}$ 值表の優先度を更新する (行 $23,25,27,28)$ 。

行 27 の式では，ロボットの実際の行動と同じ行動がグ リーディである $\mathrm{R}$ 值表の優先度について, その $\mathrm{R}$ 值表の平 均報酬の近似である $\rho$ が累積されていく。この処理によっ て， $\rho$ の值の大きい，すなわち期待報酬の大きい $\mathrm{R}$ 值表は より選択されやすくなる。一方, グリーディに選択した行 動の報酬が良くなかった $\mathrm{R}$ 值表や，これまでの行動の結果 が良くない $\mathrm{R}$ 值表の優先度には, 負ないし小さい正の值が 加算されるため, 徐々に選択される確率が減っていく。結 果として, 適切な行動を決定可能な (すなわち適切な行動 が，その R 值表上でグリーディとなっていた) 回数の多い $\mathrm{R}$ 值表が，実際の行動を決定することになると考えられる。

例えば局所解に陥った際は，この状況の継続につながる 行動がグリーディである $\mathrm{R}$ 值表の $\rho$ 值は, 即時報酬が負で あれば，行動と共に低下していく。したがって，こうした $\mathrm{R}$ 值表に対応する優先度も徐々に下がるため, 別の行動が

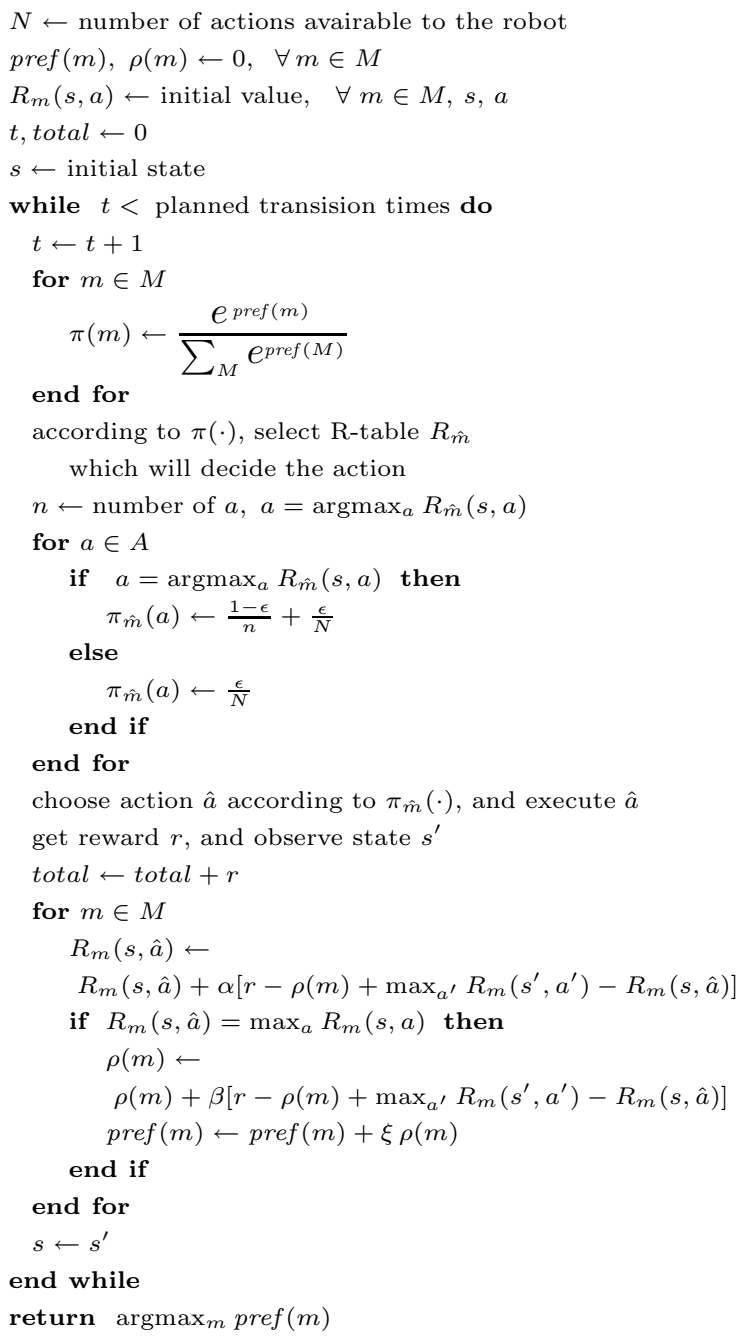

図 1 提案手法の処理。詳細は本文参照

Fig. 1. Procedure of the proposed method.

グリーデイになっている $\mathrm{R}$ 值表の選択確率が相対的に増加 する。この結果, 探索が促進され, 局所解から離脱する可 能性が高くなる。

\section{4. グリッドワールド実験}

提案手法を実行すると, 高確率で使用される $\mathrm{R}$ 值表が絞 り込まれ, 従来の $\mathrm{R}$ 学習法より高速に学習が進むことを検 証するために，グリッドワールドにおける実験を行った。

\section{$\langle 4 \cdot 1\rangle$ 実験条件}

$\langle\mathbf{4} \cdot \mathbf{1} \cdot \mathbf{1}\rangle \quad$ 実験コース 設定したロボットの行動環境 を図 2 に示す。ロボットは, 図 2 左の $S$ から出発し, 図 2 右の 4 行動のうち 1 つを選択し, 実行する。実線は壁を示 し, この壁に向かって行動した場合, 元の場所に止まるも

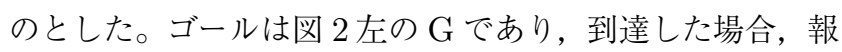
酬 1 が与えられる。それ以外の行動の報酬は 0 とし, すな わち遅延報酬が与えられる環境となる。ゴール到達後は $\mathrm{S}$ に戻って，規定行動回数まで行動を続けるものとした。

また，ロボットには前後左右に 4 つの近接センサが搭載 


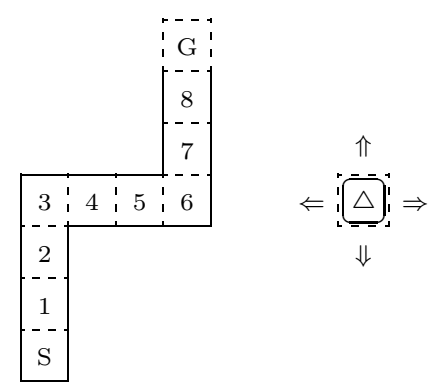

図 2 グリッドワールド実験における実験環境

(左) 及びロボットの行動 (右)

Fig. 2. Experimental settings of section 4. The experimental field (left) and robot's action (right).

され，それぞれの方向に衝突なしに移動可能であれば 0 , 移 動すれば壁に衝突する場合 1 と観測するものとした。さら に，グローバルなセンサを 1 つ持ち，このセンサで，コー スの $\mathrm{S}$ から 5 にいるときには 0,6 から 8 にいるときには 1 を観測するものとした。

この実験は，簡単な内容ではあるが，ロボットはいずれ のセンサ (の組合せ) を用いても，複数の状態において同一 の観測しか得ることができない(例えば状態 1 と 2) ため, 部分観測課題となっている。ただし，グローバルセンサを 用いることで，近接センサのみの場合に比べエイリアス状 態は減少しており，近接センサのみを用いた場合に発生す る, 状態 $1,2,7,8$ の全てが同一観測となる深刻なエイリ アスは回避される $(6$. 参照 $)$ 。

$\langle 4 \cdot 1 \cdot 2\rangle$ 学習パラメータ強化学習に用いた各パラ メータは以下の通りである。

(1) $\mathrm{R}$ 值表の学習率 $(\alpha)$

(2) $\rho$ の学習率 $(\beta)$ 0.001

(3) 各 $\mathrm{R}$ 值表の優先度の変化速度パラメータ $(\xi)$

(4) 探索行動選択確率 $(\epsilon)$

各パラメータの值に関しては，一般的と思われる值を採用 し，とくに最適化は行っていない。

$\langle\mathbf{4} \cdot \mathbf{2}\rangle$ 実験とその結果 以上の条件で，提案手法を 用いて 1,000,000 回行動させた。実験では, 上述のグロー バルなセンサは必ず用いるものとし，それ以外の 4 センサ について，1つ以上のセンサの全ての組合せを各々利用す る，15の R 学習器を並列させた。結果を図 3 に示す。提 案手法適用時の実験開始時からの平均獲得報酬を，10 実験 で平均し，10 行動毎に実線でプロットした。併せて，平均 から標準偏差分離れた值を表示した。なお, 横軸は行動回 数で, $\log$ スケールでプロットした。

また, 比較のため, 従来手法の $\mathrm{R}$ 学習の結果を, 破線で 示した。従来手法の $\mathrm{R}$ 学習では, 全てのセンサを利用する ものとした。なお，パラメータについては，〈4・1·2〉の (1), (2), (4) と同一とし， $\epsilon$-greedy 探索手法を適用した。

この課題は, 比較的単純であり, 従来手法でも学習が可 能である。実験終了時, 従来手法と同等の平均獲得報酬に

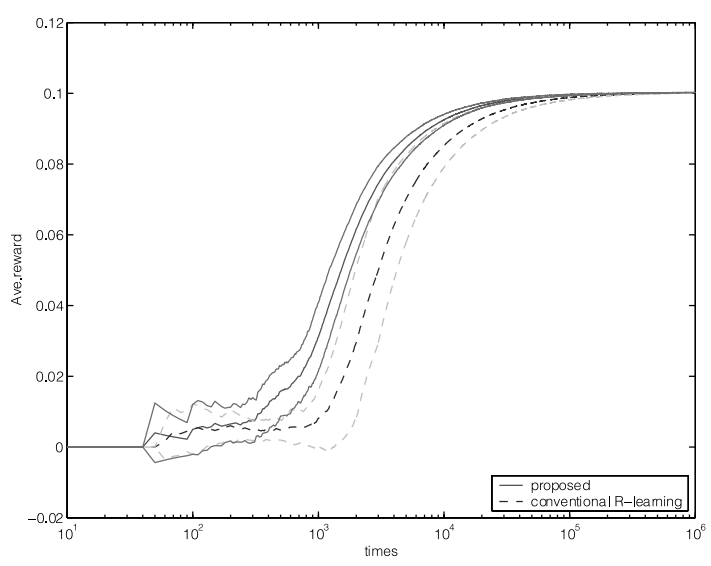

図 3 グリッドワールド実験における平均獲得報 酬の推移。提案手法 (実線) 及び従来手法の $\mathrm{R}$ 学習 (破線)の結果。実験開始時からの平均獲得報酬の 10 実験平均及び平均值から標準偏差分離れた值を プロット。横軸は行動回数で, $\log$ 表示している

Fig. 3. Average reward of grid world experiment.

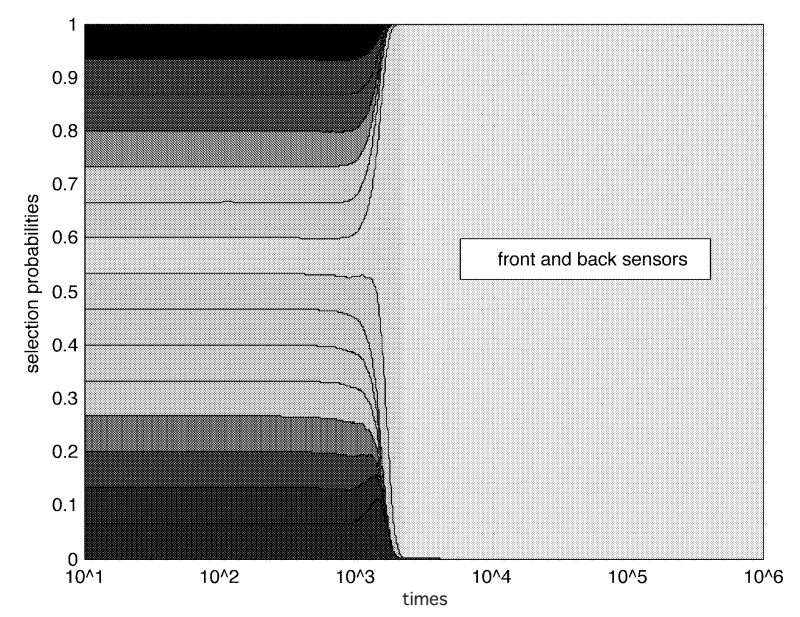

図 4 グリッドワールド実験における各強化学習 器の選択確率の推移。横軸は行動回数で, $\log$ 表 示している

Fig. 4. Selection probabilities learned by proposed method.

達していることから，提案手法でも学習が行われたと判断 される。一方, 平均獲得報酬の立ち上がりは, 従来手法と 比較して, 提案手法の方がやや早い。この例のような単純 な課題でも, 学習速度の面で優位性があることが判る。

また，提案手法を適用した実験の 1 つにおいて，各強化 学習器の選択確率の推移を 10 行動毎にプロットした結果 を, 四 4 に示す。手法の適用により, 学習器の選択が進み, およそ 10,000 行動程度で, 前及び後ろのセンサを用いる学 習器に収束している。

\section{5. シミュレータ実験}

より現実的な課題による提案手法の有効性評価のため, Khepera ロボット用に開発された, Cyberbotics 社製のシ ミュレータ Webots2.0.8 ${ }^{(6)}$ 上で, シミュレーション実験を 
実施した。

\section{$\langle\mathbf{5} \cdot \mathbf{1}\rangle \quad$ 実験条件}

$\langle\mathbf{5} \cdot \mathbf{1} \cdot \mathbf{1}\rangle$ ロボット及び行動環境＼cjkstart実験に用いたロボッ ト及びその行動環境を図 5 に示す。ロボットは，実際の Khepera ロボットの物理的特徵に基づき, 直径約 $5 \mathrm{~cm}$ の円 筒型で, 外周に沿って到達距離約 $5 \mathrm{~cm}$ の近接センサが 8 つ 搭載されている (図 5 右参照)。センサ值は，0(遠い) から 1023(近い)の間の整数值で，これらの值を 5 分類に離散化 (0-229, 230-329, 330-699, 700-909, 910-1023) して用い た。このセンサ值には $10 \%$ のワイトノイズが乗せられて いる。

$\langle\mathbf{5} \cdot \mathbf{1} \cdot 2\rangle$ 行動目標, 報酬及び強化学習パラメータ 学 習の目的は，壁に接触することなく，できるだけ環境内を 動き回る行動の獲得である。このためには，障害物を避け る一方で, 直進行動を優先させ, 可能な限り回転せずに行 動することが必要となる。

ロボットにこうした行動を獲得させるため，ロボットが 選択した行動及び行動の結果に基づく即時報酬を与えた。 ロボットが選択可能な行動は 5 つ, すなわち, 表 1 の通り とした。また，行動の結果に伴う報酬は，

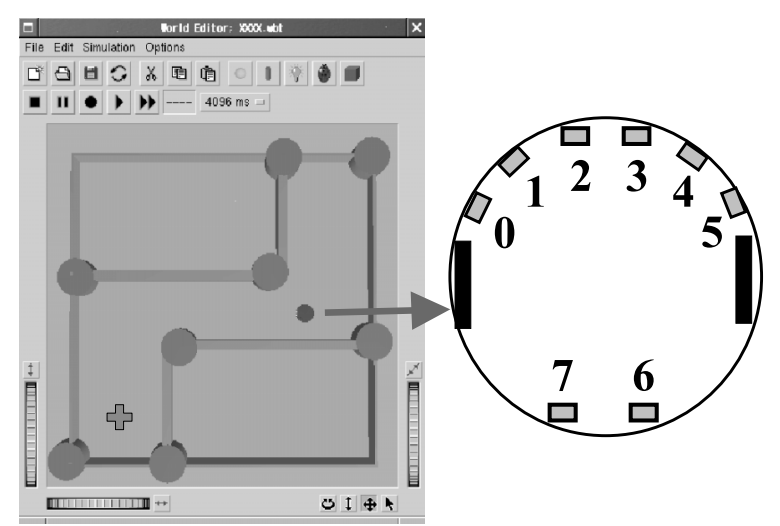

図 5 ロボット (右図) 及びその行動環境。右図 中，黒い部分が車輪，網掛け部分が接近センサの 取付位置及び向きを示している。なお，図中の+ 印は，実験の開始位置である

Fig. 5. Experimental settings: the experimental field (left) and the position of the sensors on the robot (right).

表 1 ロボットのとり得る 5 行動。右輪及び左輪 の速度コマンド， 1 秒間にロボットの中心が移動 する距離, 及び角度変化の概算值を示す。距離の 単位は $\mathrm{mm}$ ，角度の単位は。である

Table 1. Five actions available to the robot.

\begin{tabular}{l|rr|rr}
\hline & \multicolumn{2}{|c|}{ speed command } & \multicolumn{2}{c}{ translation } \\
& right wheel & left wheel & distance & degree \\
\hline forward & +1.0 & +1.0 & 8.0 & 0.0 \\
right forward & 0.0 & +1.0 & 3.6 & 8.7 \\
left forward & +1.0 & 0.0 & 3.6 & 8.7 \\
right rotation & -1.0 & +1.0 & 0.0 & 17.6 \\
left rotation & +1.0 & -1.0 & 0.0 & 17.6 \\
\hline
\end{tabular}

（1）壁への異常接近 $-0.5$

(2) 直進 $+0.01$

(3) 右/左方向への前進 $-0.01$

（4） (その場での) 右/左転 $-0.03$

の通りである。なお, 以上の実験設定は, 文献 (7) を参考 にした。

壁への異常接近の判定には, ロボットの近接センサデー 夕を用いた。すなわち, 1 つ以上センサ值が 910 以上となっ た場合，異常接近が生じたものとし，上述 (1) の負の報酬を 与えた。しかし，センサに死角があるため，センサ值のみ では壁への異常接近が記述できないことがわかった。コー ナの角部分にロボットのタイヤが接触する場合がそれであ り, 円筒形の物体 (図 5 左で壁の曲がり角部分の円) を配置 することでコーナ部分を滑らかにし，この問題を解消した。

なお，強化学習パラメータに関しては，〈4·1・2〉と同一 とした。

\section{$\langle 5 \cdot 2\rangle \quad$ 実験と結果}

$\langle\mathbf{5} \cdot \mathbf{2} \cdot \mathbf{1}\rangle$ 実験 1 : 提案手法 利用センサが 3 つ以下 のセンサ集合 $(92$ 通り) から, 一様ランダムに 20 のセン サ集合を選ぶ。これに, 全センサを用いるセンサ集合を加 え, 計 21 のセンサ集合を要素とする集合を $M$ とする。全 センサ利用のセンサ集合を含めた理由は，ランダム選択の 20 のセンサ集合のみでは, 必要なセンサがないため学習が 原理的に不可能または非常に難しくなる場合があり得ると 考えられるためである。ロボットは，行動環境の一端の特 定の位置 (図 5 左十印) に, 図下方を向いて置かれた状態 で実験を開始し，1 実験当たり 6,240,000 回の行動を選択・ 実行させるものとした。

実験の結果は，表 2 の通りである。この表は，提案手法 を適用した 10 実験に関して，実験開始時から終了時まで の平均獲得報酬を表している。さらに, 図 6 に平均獲得報 酬の推移を示す。横軸は行動回数 (単位: 10,000 行動) であ り, 縦軸は学習開始時からの平均獲得報酬を 10,000 行動毎 にプロットした。提案手法 10 実験の平均及び平均からの標 準偏差を実線で示した。また, 過去 10,000 行動の間に壁に

表 2 実験 $1<5 \cdot 2 \cdot 1\rangle$ 提案手法適用時の実験結果。 実験終了時の平均獲得報酬

Table 2. Average rewards of the proposed method.

\begin{tabular}{l|r}
\hline & \multicolumn{2}{|c}{ average reward } \\
(end of experiments)
\end{tabular}




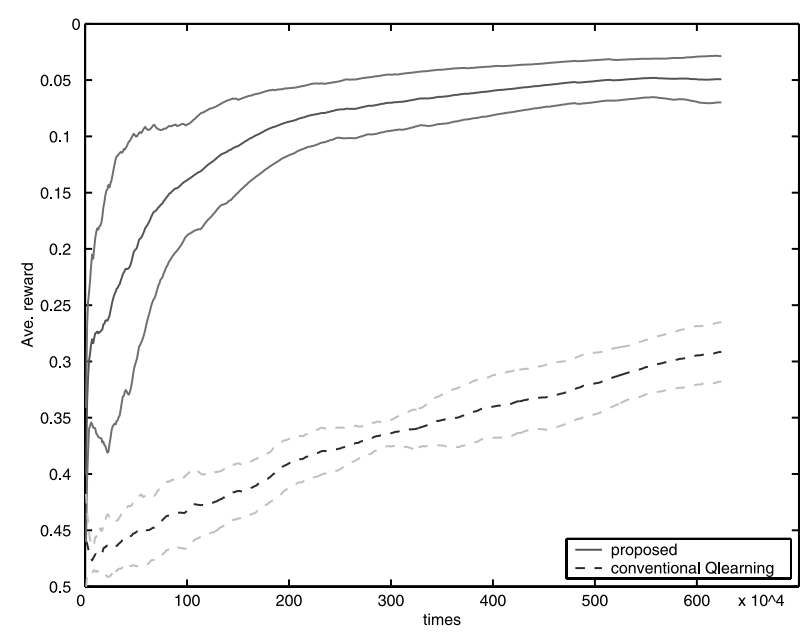

困 6 平均獲得報酬の推移。実験 $1\langle 5 \cdot 2 \cdot 1\rangle$ (実 線) 及び実験 $5\langle 5 \cdot 2 \cdot 5\rangle$ の $\mathrm{Q}$ 学習 (破線) の結果。 実験開始時からの平均獲得報酬 (縦軸) を 10,000 行動毎に出力。横軸は, 行動回数 (単位: 10,000 回)。10 実験の平均と, 平均から標準偏差分離れ た值を示す

Fig. 6. Average rewards averaged from the beginning plotted at every 10,000 actions.

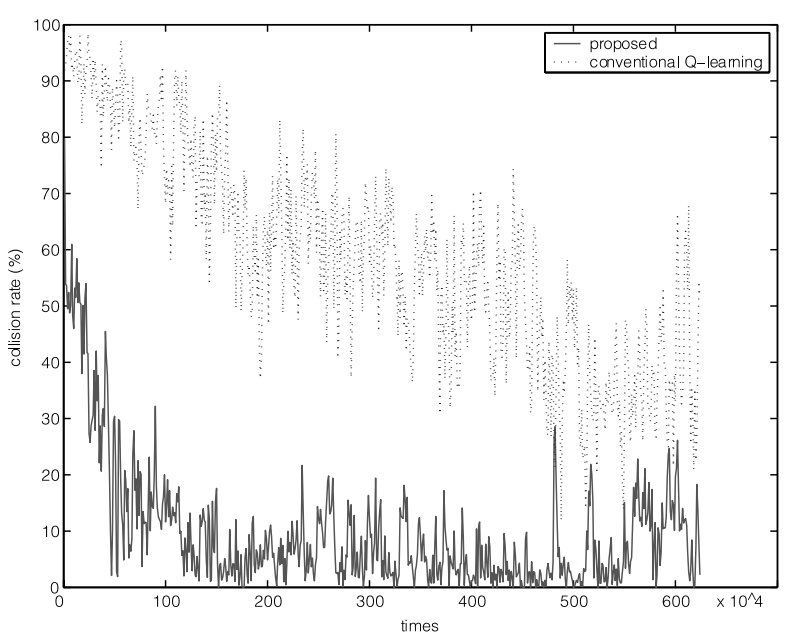

図 7 異常接近率の推移。過去 10,000 行動の異 常接近率 (単位: \%) を 10,000 行動毎に出力。横軸 は, 行動回数 (単位: 10,000 回)。実線が, 実験 1 $\langle 5 \cdot 2 \cdot 1\rangle$ 提案手法 10 実験の平均。比較のため, 実験 $5\langle 5 \cdot 2 \cdot 5\rangle$ 従来手法の Q 学習の結果 $(10$ 実 験の平均) を点線で示す

Fig. 7. Detections of walls too close. Rates in the last 10,000 actions plotted at every 10,000 actions.

異常接近した率 (単位:\%) を 10,000 行動毎にプロットした 結果を図 7 に示す。横軸が行動数 (単位: 10,000 行動), 縦 軸が異常接近した率の 10 実験平均を実線で表している。

$\langle\mathbf{5} \cdot \mathbf{2} \cdot \mathbf{2}\rangle$ 実験 $2: \mathrm{R}$ 学習 $(\epsilon-$ greedy $) \quad$ 次に, 従来 手法の R 学習を適用した結果を, 表 3 最上段に示す。探索 手法としては， $\epsilon$-greedy を用い,〈4·1·2〉の (1), (2), (4) と同一の強化学習パラメータを採用し, 実験終了時の平均
表 3 実験 $2\langle 5 \cdot 2 \cdot 2\rangle, 5\langle 5 \cdot 2 \cdot 5\rangle$ の結果。従来手 法 (全センサを用いる) による R/Q/Sarsa 学習の 実験 10 回の平均獲得報酬の平均を下行に示した。 Q/Sarsa 学習の結果に関しては $25 \cdot 2 \cdot 5\rangle$ 本文参照

Table 3. Average rewards of conventional method ( $\epsilon$-greedy exploration method). Mean values of ten experiments.

\begin{tabular}{l|r}
\hline & $\begin{array}{c}\text { average reward } \\
\text { (end of experiments) }\end{array}$ \\
\hline R-learning (with all equiped sensors) & -0.4945 \\
\hline Q-Learning (with all equiped sensors) & -0.2915 \\
Sarsa (with all equiped sensors) & -0.2964 \\
\hline
\end{tabular}

表 4 実験 $3\langle 5 \cdot 2 \cdot 3\rangle$ UE を用いた実験結果。実 験終了時の平均獲得報酬を示す

Table 4. Average rewards of conventional Rlearning (UE exploration method).

\begin{tabular}{l|r}
\hline & $\begin{array}{c}\text { average reward } \\
\text { (end of experiments) }\end{array}$ \\
\hline experiment 3-1 & -0.3401 \\
experiment 3-2 & -0.3446 \\
experiment 3-3 & -0.3338 \\
experiment 3-4 & -0.3371 \\
experiment 3-5 & -0.3409 \\
\hline experiment 3 (R-learning by UE) & mean \\
\hline
\end{tabular}

表 5 実験 $4\langle 5 \cdot 2 \cdot 4\rangle$ softmax を用いた実験結果。 実験終了時の平均獲得報酬を示す

Table 5. Average rewards of conventional Rlearning (softmax exploration method).

\begin{tabular}{l|r}
\hline & $\begin{array}{c}\text { average reward } \\
\text { (end of experiments) }\end{array}$ \\
\hline experiment $4-1$ & -0.4647 \\
experiment $4-2$ & -0.2210 \\
experiment $4-3$ & -0.4412 \\
experiment $4-4$ & -0.0564 \\
experiment $4-5$ & -0.4343 \\
\hline experiment 4 (R-learning by softmax) & mean \\
\hline
\end{tabular}

獲得報酬を 10 実験で平均した。なお, 処理の詳細は, 付図 1 参照。

$\langle\mathbf{5} \cdot \mathbf{2} \cdot 3\rangle$ 実験 3 ： R 学習 (UE) 従来手法の R 学 習において，探索手法として UE ${ }^{(4)}$ を用いた実験の結果を 表 4 に示す。 5 回の実験の終了時の平均獲得報酬及びこれら の平均を記した。グリーディな行動を選択する確率 $p=0.9$ とし，パラメータ $c$ に関しては, 文献 $(4)$ と同一の $c=60$ を採用した。また, 文献 $(4)$ における $N_{f}(s, a)$ については, 初期值 $=1$ とした。なお，処理の詳細は，付図 1 参照。

$\langle 5 \cdot 2 \cdot 4\rangle$ 実験 4 ：R 学習 (softmax) 従来手法の $\mathrm{R}$ 学習において, softmax 探索手法を用いた実験の結果を 表 5 に示す。温度パラメータは定数 1 とし,〈4・1・2〉の (1) 及び (2) と同一の強化学習パラメータを採用した。5 回の 実験における終了時の平均獲得報酬と, それらの平均を記 した。なお，処理の詳細は，付図 1 参照。

$\langle\mathbf{5} \cdot \mathbf{2} \cdot \mathbf{5}\rangle$ 実験 5 : Q/Sarsa 学習 $Q$ 及び Sarsa 学 
習を適用した 10 実験に関して，実験開始時からの平均獲 得報酬を表 3 の下 2 段に示す。実験では，割引 $(\gamma=0.9)$ を用い, 強化学習パラメータは $44 \cdot 1 \cdot 2\rangle$ (1), (4) と同じ 值とした。探索手法は $\epsilon$-greedyである。なお，処理の詳細 は，付図 2 参照。

また，Q 学習の結果について，平均獲得報酬の推移を図 6 に破線で示す。さらに，過去 10,000 行動の間に壁に異常 接近した率 (単位:\%) を 10,000 行動毎にプロットした結果 を図 7 に点線で示す。

$\langle 5 \cdot 2 \cdot 6\rangle$ 実験 6 : CMAC+R 学習 強化学習にお いて，推定価值関数の近似を行い，学習の高速化を図る手 法として，タイルコーディングを用いる手法が提案されて いる(5)。この手法は, 歴史的経緯から CMAC (cerebellar model articulation controller) ${ }^{(8)}$ とも呼ばれる。

CMAC では，複数の相異なるタイリングを用いる。タイ リングは，重なりあわない複数のタイルの集合であり，そ れぞれのタイルが各タイリングにおける受容野に相当する。 観測状態は，その状態が属するタイルの集合で表現される。 すなわち, 状態 $s$ がタイリング $m$ のタイル $n$ に属する場 合 $B_{m, n}(s)=1$, それ以外では $B_{m, n}(s)=0$ とする。行動 $a$ をとる $\mathrm{Q}$ 值を近似表現するため, 各夕イル毎にウエイト $w_{m, n}(a)$ を定める。すなわち,

$$
Q(s, a) \approx \sum_{m, n} w_{m, n}(a) B_{m, n}(s)
$$

とする。各ウエイトは，行動後，TD 誤差を小さくするよ う更新される。

本実験では，可能な全てのセンサ集合に対応させてタイ リングを作成した。したがって，255のタイリングを用い た。CMACをAcrobotの学習に適用した例 (5)では，夕イ リングとして，可能なセンサ集合の全てを用いている。ま た，センサリーディングに関する汎化を得るため，各セン サ集合に対して，ランダムにオフセットさせた複数の夕イ リングを準備している。この例を参考にした。なおセンサ 值に関しては，各タイリングでのオフセットはさせなかっ た。すなわちく $5 \cdot 1 \cdot 1>$ で説明した離散化が，そのまま各夕 イリングにおけるタイル分割となっている。このため，各 タイリングの観測内容は，提案手法で想定する各学習器の 観測と完全に同一である。なお，提案手法では，これらの 学習器の部分集合を用いた点と, 学習や行動決定の方法が 異なる。

CMAC を適用した R 学習の実験結果を表 6 に示す。実 験ではく $4 \cdot 1 \cdot 2\rangle$ の $(1),(2),(4)$ と同一の強化学習パラメー 夕を用い， $\epsilon$-greedyによる探索を行った。なお，処理の詳 細は, 付図 3 参照。

$\langle\mathbf{5} \cdot \mathbf{2} \cdot \mathbf{7}\rangle$ 実験 7 : CMAC+Q 学習 $\mathrm{CMAC}$ と $\mathrm{R}$ 学習の併用では，R 学習が局所解に入って学習が進まない 可能性がある。このため, CMAC と Q 学習を併用した実 験を行った。結果を表 7 に示す。なお，この実験でも，実 験 6 と同様のタイリングを用いた。また，割引 $(\gamma=0.9)$
表 6 実験 $6\langle 5 \cdot 2 \cdot 6\rangle$ の結果。実験終了時の平均 獲得報酬を示す

Table 6. Results of R-learning with CMAC method.

\begin{tabular}{l|r}
\hline & $\begin{array}{c}\text { average reward } \\
\text { (end of experiments) }\end{array}$ \\
\hline experiment 6-1 & -0.4909 \\
experiment 6-2 & -0.4996 \\
experiment 6-3 & -0.4996 \\
experiment 6-4 & -0.0095 \\
experiment 6-5 & -0.4903 \\
\hline experiment 6 (R-learning with CMAC) & mean \\
\hline
\end{tabular}

表 7 実験 $7\langle 5 \cdot 2 \cdot 7\rangle$ の結果。実験終了時の平均 獲得報酬を示す

Table 7. Results of Q-learning with CMAC method.

\begin{tabular}{l|r}
\hline & $\begin{array}{c}\text { average reward } \\
\text { (end of experiments) }\end{array}$ \\
\hline experiment 7-1 & -0.0659 \\
experiment 7-2 & -0.0199 \\
experiment 7-3 & -0.3317 \\
experiment 7-4 & -0.0722 \\
experiment 7-5 & -0.2246 \\
\hline experiment 7 (Q-learning with CMAC) & mean \\
\hline
\end{tabular}

表 8 実験 $8<5 \cdot 2 \cdot 8>$ の結果。実験終了時の平均 獲得報酬 $(5,10$ 実験の平均) を示す

Table 8. Average rewards in the experiments with vaired parameters.

\begin{tabular}{l|ll|l|l}
\hline & $\beta$ & $\xi$ & \multicolumn{2}{|c}{$\begin{array}{c}\text { average reward } \\
\text { (end of experiments) }\end{array}$} \\
\hline R-learning & 0.001 & 0.6 & -0.0504 & mean of 5 experiments \\
with & 0.001 & 0.1 & -0.0564 & mean of 5 experiments \\
proposed & & & -0.0492 & mean of 10 experiments \\
method & 0.01 & 0.6 & -0.0727 & mean of 5 experiments \\
& 0.01 & 0.1 & -0.1160 & mean of 5 experiments \\
\hline
\end{tabular}

を用い, 強化学習パラメータは, 〈4·1·2〉の (1), (4) と同 一とし， $\epsilon$-greedyによる探索をさせた。なお，処理の詳細 は, 付図 3 参照。

$\langle\mathbf{5} \cdot \mathbf{2} \cdot 8\rangle$ 実験 8 : 提案手法のロバスト性 提案手法 において, 強化学習パラメータ $(\langle 4 \cdot 1 \cdot 2\rangle$ 参照) を変えて実 験した結果は表 8 の通りである。各パラメー夕設定におい て, 実験 1の 1-1 から 1-5 と同一のセンサ集合を用いて学 習させた 5 実験の平均を示す (実験 1 に関しては，10 実験 の平均も併記した)。

\section{6. 考 察}

4.の実験では, 従来手法の $\mathrm{R}$ 学習と比較して, 提案手法 の優位性が示された。なお, 前後左右の 4 つの近接センサ のみを利用した場合, 従来手法の $\mathrm{R}$ 学習, 提案手法共に学 習が進まなかったため,〈4・1・1〉の通りグローバルセンサ を追加した。一方，Q学習では，このようなセンサの追加 なしでも学習が可能(9) であった。これはグローバルセン 
サを用いない場合, 状態 $1,2,7,8$ がエイリアスとなるが, 学習速度の速い $\mathrm{R}$ 学習にとって, とくに性質の悪いエイリ アスとなったものと推測される。

部分観測状態が存在する場合，一般には Q 学習であって も収束は保証されない。 $\mathrm{R}$ 学習の場合は，完全観測の場合 にもその収束性は証明されていないため，提案手法の妥当 性を数学的に示すことは極めて困難である。しかしながら， 完全観測状態である場合や，不完全観測状態であっても， 4.に示したように個々の R 学習器におけるグリーディな方 策が，ある方策に収束する $(\mathrm{R}$ 值は収束しない) 場合には, 提案手法が収束することは，我々が行った実験の範囲では 確認している。この場合，提案手法が収束するというのは， ある学習器または学習器群が確率 1 で選択され, それらが, 同じ方策を持つようになることである。なお，探索を許し ているので，それによる擾乱があっても，もとの方策を再 学習するということである。

提案手法は，行動決定に用いる $\mathrm{R}$ 值表の選択基準として $\rho$ の累積值を用いている。このため, 不完全観測状態であっ て， $\rho$ 值の立ち上がりが非常に速い $\mathrm{R}$ 学習器が，実際には どの方策にも収束しない学習器であった場合, 学習器選択 基準の更新 (図 1 行 27 ) が間に合わず, この学習器が選択 され続ける可能性がある。

5.の実験に関して, $\langle 5 \cdot 2 \cdot 1\rangle$ の結果は, $\langle 5 \cdot 2 \cdot 2\rangle$ ないし $\langle 5 \cdot 2 \cdot 7>$ のいずれと比較しても高い成績である。すなわち, 提案手法の適用によって迅速な学習が実現された。以下，提 案手法の結果が他手法より優れている理由についての考察 を最初に記し，続いて各実験結果に関して考察する。

この実験課題では，ロボットが壁にトラップされ学習が 進まなくなる現象がしばしば発生する (本論文では, 壁に接 触もしくは異常接近した状況が継続することを，トラップ 状況にあると表現するものとする)。実験の設定では，壁に 一定以上近付き過ぎた場合, 壁から十分な距離まで離れる まで，選択した行動によらず一定の負の報酬が与えられ続 けるため, $r-\rho$ は R 值が定常化するより速く 0 に近付く。 このため, 得られた報酬が学習に正当に反映されない。し たがって，ある時点でグリーディであった状態一行動対が保 存されやすく，学習結果がその状態一行動対の影響を受ける ことになる。これにより局所解が発生しやすくなる，すな わち，グリーディな行動選択によって得られる行動列は最 適でない行動列に陥ることになると予想される。なお，Q 学習では，こうした局所解は基本的には発生しない。

$\mathrm{R}$ 学習を用いた実験 $(\langle 5 \cdot 2 \cdot 2\rangle\langle 5 \cdot 2 \cdot 4\rangle,\langle 5 \cdot 2 \cdot 6\rangle)$ に対する 優位性に関しては，提案手法の局所解を回避する効果によ るものと推測される。壁にトラップされている際の, 提案手 法と従来手法の $\mathrm{R}$ 学習との比較を行った。トラップの深刻 さの指標として, センサ值が異常接近值である 910 に達し たセンサの個数を用いた。困 8 は, $\langle 5 \cdot 2 \cdot 1\rangle$ 及び $5 \cdot 2 \cdot 2\rangle$ と 同一の条件で行った実験において，実験開始から約 35,000 回行動させた際，值が異常接近值を超えたセンサ数を 20 行 動毎に平均しプロットしたものである。縦軸がセンサ数, 横

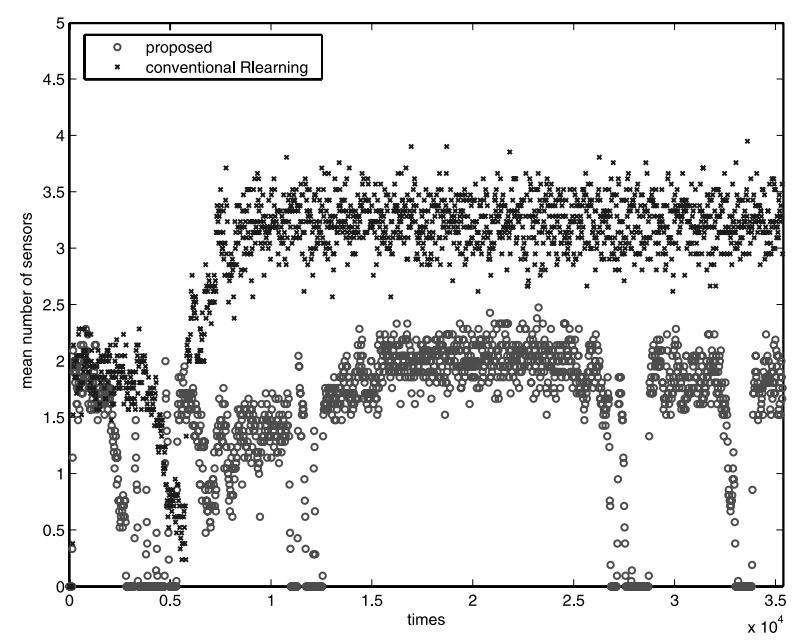

図 8 センサ值 $>910$ のセンサ数の推移。20行 動の間の平均值を 20 行動毎にプロット

Fig. 8. Mean number of sensors that detect walls too close. Plotted at every 20 actions.

軸は行動回数を示す。丸印が提案手法，X印が従来手法の 結果である。

提案手法採用時の值が一貫して低いことは，実際に状態 表現の分析により確認した結果，異常接近を示すセンサ数 が少ない状態への探索が促進されたことを反映していると 推測され，この探索促進の結果トラップの脱出ないし回避 が可能となったと考えられる。

一方, $\langle 5 \cdot 2 \cdot 5\rangle$ の $\mathrm{Q}$ 及び Sarsa 学習と比較して, 提案手 法の成績が良い点は, トラップされていない状態において, $\mathrm{R}$ 学習が $\mathrm{Q}$ 及び Sarsa 学習より早く直進行動を学習するた めと推察される。これは, $\mathrm{R}$ 学習が $\mathrm{Q}$ 学習より高速である との Schwartzの指摘(2)を裏付ける結果と考えられる。

$\epsilon$-greedy 手法を用いた従来手法の $\mathrm{R}$ 学習では, $\langle 5 \cdot 2 \cdot 2\rangle$ の結果が示すように最低報酬值 $(-0.5)$ に近い平均獲得報 酬しか得られていない。この成績は，〈5・2・5〉における従 来手法の Q 及び Sarsa 学習の結果にも遠く及ばず, きわめ て悪い結果といえる。これは, 大半の実験において, 実験 の初期段階に壁に衝突しそのまま脱出できなかったためで ある。

なお $\mathrm{R}$ 学習では, $\mathrm{Q}$ 学習より探索行動を増やすことで 好成績が得られる場合があるとの指摘 ${ }^{(4)}$ に基づき， $\epsilon$ 值な いし $\mathrm{R}$ 值の学習率 $(\alpha)$ の值の割増し, オプティミスティッ ク初期值の採用等を試したが，効果は確認できなかった。 実験当初は, 細かく動きながら壁からの脱出を試みている ように見えたが，次第にそうした試みも弱まる。これは文 献 (3) で報告されている状況と似ており, 局所解に陥って いると推定される。

$\langle 5 \cdot 2 \cdot 3\rangle$ では，探索手法として UE を用いた従来手法の R 学習を適用したが, この結果も, 提案手法は勿論, $\langle 5 \cdot 2 \cdot 5\rangle$ の Q 及び Sarsa 学習の成績に及ばない。ただし, $\langle 5 \cdot 2 \cdot 2\rangle$ のように長期間壁にトラップされる現象はあまり見られず, 
探索を増した効果はあると思われる。

なお UEは，利用頻度の少ない行動を選んで探索する探 索手法である。文献 (4) では，パラメー夕 $c$ の值が $\mathrm{R}$ 学習 の成績のばらつきに大きな影響を与えると報告されている。 しかし, 適切な值の設定には実験の繰返しが不可欠であり, 現実的には難しい。

〈5・2・4〉で採用した softmax 手法は, 文献 $(3)$ では良い 評価が与えられていないが，我々の実験では $\mathrm{R}$ 学習を用い た従来手法中最も成績が良かった。とくに 5 実験中 2 回の 高い平均獲得報酬が得られた実験では, 比較的早い段階で 壁沿い行動を獲得していた。一方，他の 3 実験ではこの行 動の獲得が十分には進まず，壁にトラップされることが多 いため，低い平均獲得報酬にとどまった。

$\langle 5 \cdot 2 \cdot 5\rangle$ で採用した従来手法の Q 及び Sarsa 学習は, 本 研究の実験課題では, 提案手法を除く $\mathrm{R}$ 学習手法を適用し た実験より良い成績であった。しかし，図 6 に示した通り， 従来手法の $\mathrm{Q}$ 学習が約 6,000,000 行動後に達した平均獲 得報酬值は，提案手法では約 100,000 行動も要せずに得て いる。この違いにより, 従来手法の $\mathrm{Q}$ 学習は提案手法に劣 る結果となっている。さらに図 7 に示したように, 壁に異 常接近する率についても, 従来手法の $\mathrm{Q}$ 学習は提案手法よ り高く, またそれが低下する速度が遅いため, 提案手法に 劣っているといえる。

$\langle 5 \cdot 2 \cdot 6\rangle$ の 学習と CMAC の併用では, 表 6 から明ら かな通り, 学習が迅速に進む場合もあるものの, その数は 5 例中 1 例に止まっている。しかもこの例では, 実験末期 に障害物のない場所で，その場での旋回を繰返す行動を発 現することがあり，適切な方策を学習したとはいえない。

$\langle 5 \cdot 2 \cdot 7\rangle$ における Q 学習と CMAC の併用では, 表 7 の 通り, 従来手法の Q/Sarsa 学習に対する優位性が認められ るものの, 実験 6 同様, 学習速度のばらつきが大きい結果 となっている。

$\langle 5 \cdot 2 \cdot 8>$ のパラメータ值を変えた実験では，表 8 の結果 から，提案手法は，平均獲得報酬ばかりではなく，ロバス 卜性の面でも優れていると考えられる。

\section{7. 結 論}

強化学習は, 学習のための教示や事前知識を必要とせず, 望ましい行動を自律的に獲得させることが可能である反面， 実際的な課題に適用する際には，学習速度の向上 (本論文 では，環境との相互作用回数の削減) が重要な問題となる。 学習高速化に関しては，様々な試みがなされているが，本 研究では， $\mathrm{R}$ 学習を用いることで，迅速な学習の実現を目 指すと共に, 強化学習を並列的に複数用いる, すなわち複 数の $\mathrm{R}$ 值表を用いることで， $\mathrm{R}$ 学習を安定して高速に動作 させる新しい手法を提案した。

$\mathrm{R}$ 学習は, 強化学習で通常用いられる, 割引を用いた累 積報酬の代わりに，平均報酬を用いる手法で，エピソード 分割のない，行動を無限に継続する課題に適用される ${ }^{(5)}$ 。
このため, 例えばロボットを継続的に行動させながら, 望 ましい行動を獲得させるといった課題に適している。 R 学 習は, $\mathrm{Q}$ 学習等と比較して, 学習が迅速な可能性がある ${ }^{(2)}$ 反面, 行動決定手法や学習パラメータに敏感であるとの報 告もある (3) (4)。後者は R 学習が局所解へ陥りやすい性質 をもつためであり, 提案手法の適用により軽減・解消する ことができる。これにより，ロバストな学習が行えるよう になれば， $\mathrm{R}$ 学習手法の適用の幅が広がる。

ロボットが継続的に行動する強化学習課題の例として, 障害物回避行動の獲得を実験課題として取り上げ, 提案手 法の有効性をシミュレーション実験により検証した。その 結果, 従来手法の R/Q/Sarsa 学習, 及び CMAC 手法 ${ }^{(5)}$ を適用した $\mathrm{Q} / \mathrm{R}$ 学習と比較して, きわめて良い成績をあ げた。すなわち, より少ない行動回数で壁への異常接近の 回避方法やトラップからの脱出方法を学習し, 高い平均獲 得報酬を得た。したがって提案手法は, $\mathrm{R}$ 学習のロバスト 性を向上させ，学習の高速化を眓る手法として有望である と考える。

(平成 16 年 10 月 26 日受付, 平成 17 年 6 月 20 日再受付)

\section{文献}

(1) H. Kimura, K. Miyazaki, and S. Kobayashi: "A guideline for designing reinforcement learning systems", Journal of the Society of Instrument and Control Engineers, Vol.38, No.10, pp. 618-623 (1999) (in Japanese)

木村 元 ·宮崎和光・小林重信 : 「強化学習システムの設計指針」, 計測と制御, 38, 10, pp.618-623 (1999)

(2) A. Schwartz: "A reinforcement learning method for maximizing undiscounted rewards", Proceedings of the 10th International Conference on Machine Learning, pp.298-305 (1993)

(3) S. Mahadevan: "To discount or not to discount in reinforcement learning: A case study comparing $\mathrm{R}$ learning and $\mathrm{Q}$ learning", Proceedings of the 11th International Conference on Machine Learning, pp.164-172 (1994)

(4) S. Mahadevan: "Average reward reinforcement learning: Foundations, algorithms, and empirical results", Machine Learning, Vol.22, pp.159-196 (1996)

(5) R. S. Sutton and A. G. Barto: "Reinforcement Learning: An Introduction", MIT Press (1998) （邦訳 : 強化学習, 三上貞芳, 皆川雅章訳, 森北出版 (2000))

(6) Cyberbotics: "Webots 2.0 User Guide" (1999)

( 7 ) K. Samejima and T. Omori: "Adaptive state space formation method for reinforcement learning", The Brain and Neural Networks, Vol.6, No.3, pp.144-154 (1999) (in Japanese) 鮫島和行·大森隆司：「強化学習における適応的状態空間構成法」, 日本神経回路学会誌, 6, 3, pp.144-154 (1999)

(8) J. S. Albus: "Brains, Behaviour, and Robotics", BYTE Books Subsidiary of McGraw-Hill (1981)

(9) K. Ishikawa, A. Sakurai, T. Fujinami, and S. Kunifuji: "Online Sensor Selection in Reinforcement Learning Environment", IEEJ Trans. EIS, Vol.125, No.6, pp.870-878 (2005-6) (in Japanese)

石川浩一郎・櫻井彰人・藤波 努・國藤 進:「強化学習における才 ンラインセンサ選択」, 電学論 C, 125, 6, pp.870-878 (2005-6)

\section{付 録}

\section{1. 対照実験の詳細}

$\langle 5 \cdot 2 \cdot 2\rangle$ からく $5 \cdot 2 \cdot 7\rangle$ で行った対照実験のアルゴリズム を，以下に示す。 


\section{$\langle\mathbf{1} \cdot \mathbf{1}\rangle \mathbf{R}$ 学 習 付図 1 参照。}

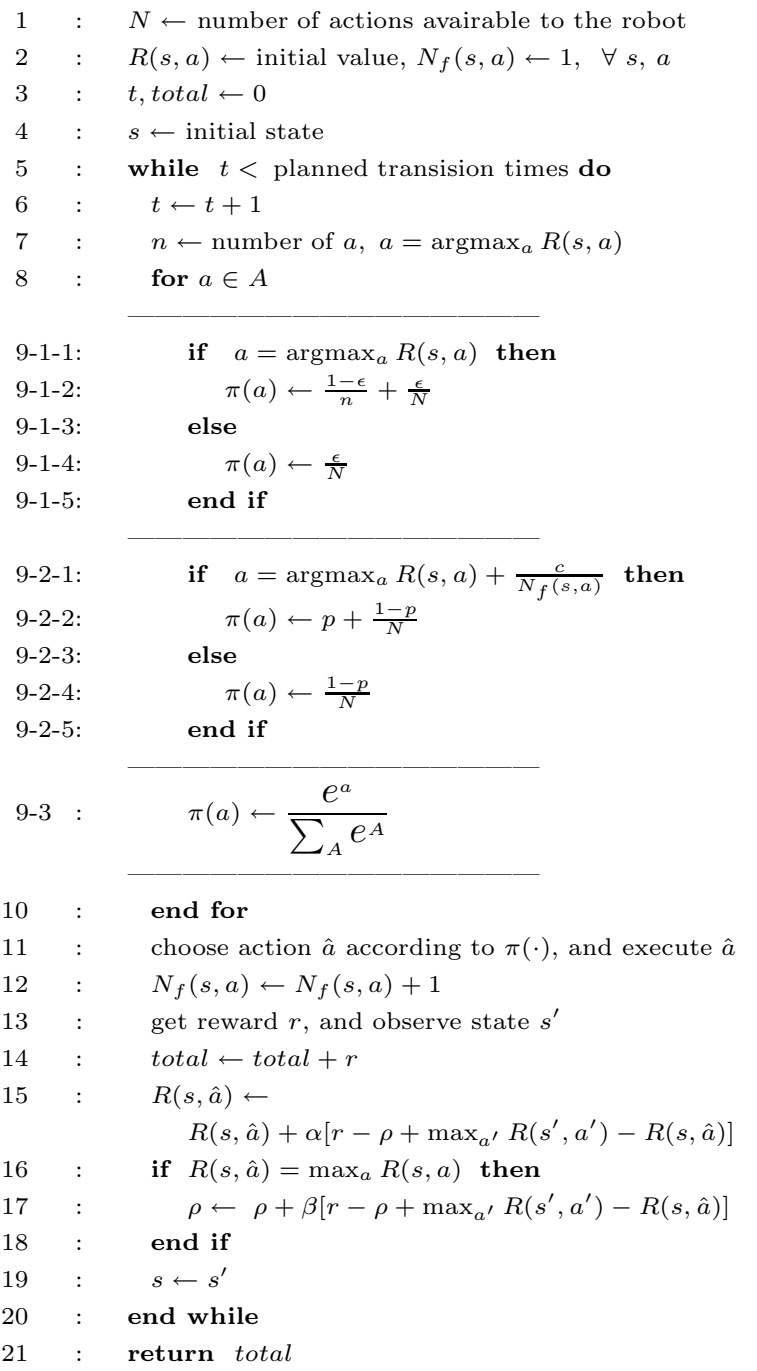

付図 1 対照実験の処理。従来手法の $\mathrm{R}$ 学習。探 索手法として, 9-1 は $\epsilon$-greedy (実験 $2\langle 5 \cdot 2 \cdot 2\rangle$ ), 9-2 は UE (実験 $3\langle 5 \cdot 2 \cdot 3\rangle$ ), $9-3$ は softmax (実 験 $4\langle 5 \cdot 2 \cdot 4\rangle)$ を用いた場合

app. Fig. 1. Procedure of conventional R-learning.

\section{$\langle\mathbf{1} \cdot \mathbf{2}\rangle \mathrm{Q} / \mathrm{Sarsa}$ 学習 付図 2 参照。}

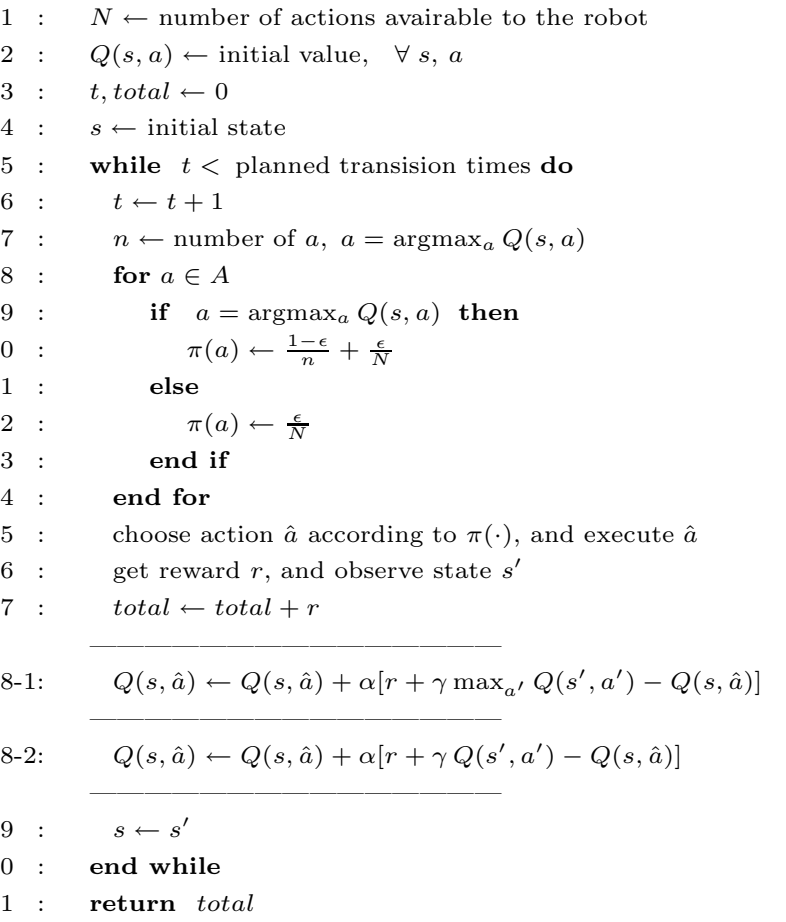

付図 2 対照実験の処理。18-1 は従来手法の Q 学習 (実験 $5\langle 5 \cdot 2 \cdot 5\rangle$ )。18-2 は従来手法の Sarsa 学習 (実験 $5\langle 5 \cdot 2 \cdot 5\rangle$ )。探索手法としては, $\epsilon$-greedy 用いた

app. Fig. 2. Procedure of conventional Q-/Sarsa learning. 


\section{$\langle\mathbf{1} \cdot \mathbf{3}\rangle \mathrm{CMAC}$ 手法 付図 3 参照。}

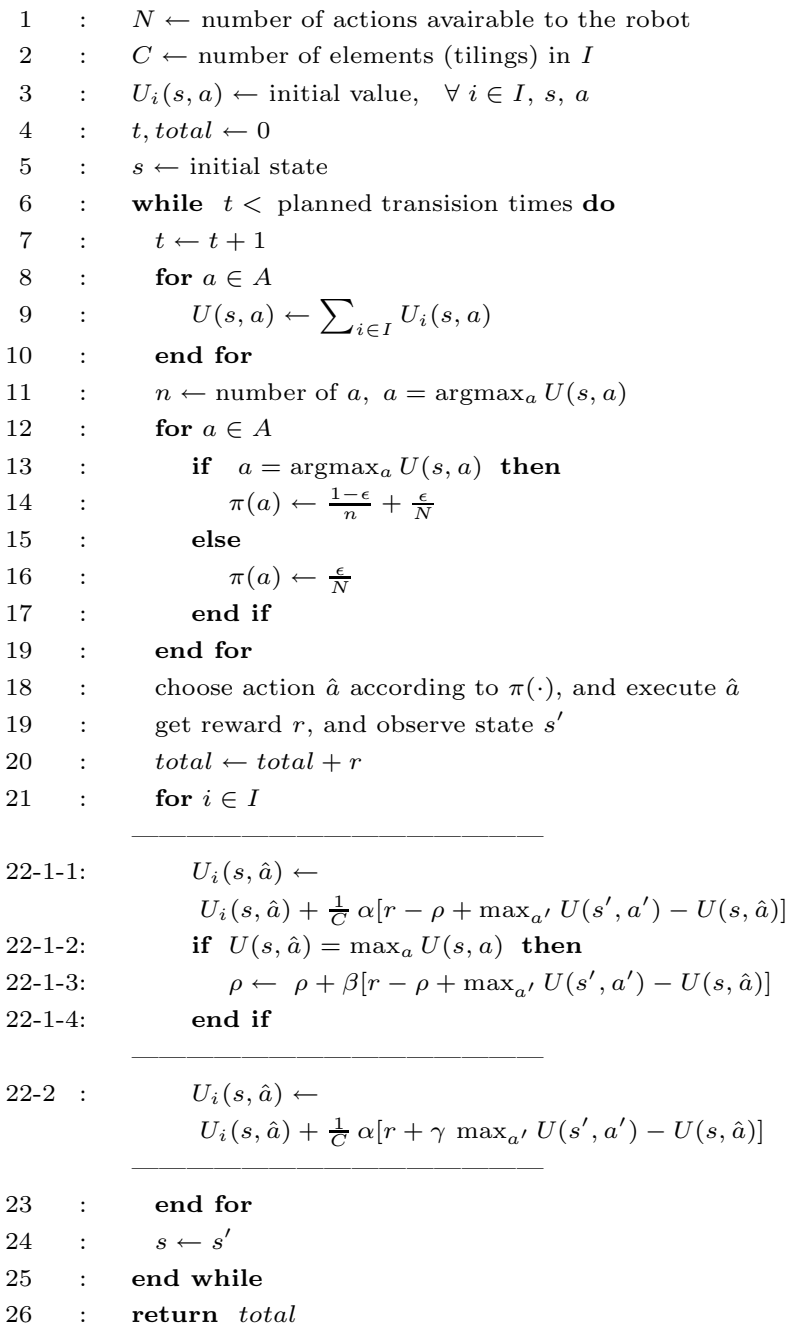

付図 3 対照実験の処理。22-1 は R 学習による CMAC (実験 $6\langle 5 \cdot 2 \cdot 6\rangle$ )。22-2 は Q 学習による CMAC (実験 $7\langle 5 \cdot 2 \cdot 7\rangle$ )。探索手法としては, $\epsilon$-greedy を用いた。なお， $U$ は状態行動価值を示 し， R 学習では $\mathrm{R}$ 值， $\mathrm{Q}$ 学習では $\mathrm{Q}$ 值となる app. Fig. 3. Procedure of the CMAC method.
石川浩－郎 (非会員) 1989 年山口大学経済学部経済法学科

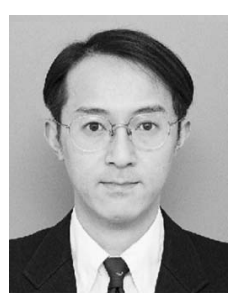
卒業。同年, 日本電気 (株) 入社。2000 年 北陸先 端科学技術大学院大学知識科学研究科博士前期課 程修了。2005 年同博士後期課程単位取得退学。 同年上り東京農工大学 産官学連携研究員。博士 (知識科学)。

櫻 井 彰 人 (正員) 1975 年東京大学工学部計数工学科卒業,

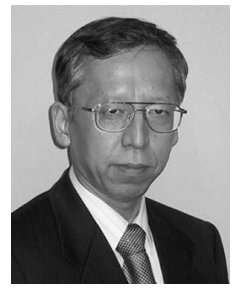
77 年 同大学院情報工学研究科修了。同年 日立製 作所入社那珂工場配属。 78 年 Dept. of Computer Science, Univ. of Illinois (MsCS 取得 (1979))。 89 年 同基礎研究所, 96 年 同中央研究所, 98 年 北 陸先端科学技術大学院大学教授を経て, 2002 年 慶 應義塾大学理工学部教授となる。博士 (工学) (東 京大学 1993)。人工神経回路網，機械学習を専門 とする。1987 年ソフトウェア科学会高橋奨励賞, 94 年, 98 年人工 知能学会研究奨励賞を受賞。ACM, INNS, AAAI, 情報処理学会, 人工知能学会, ソフトゥェア科学会, 応用数理学会各会員。

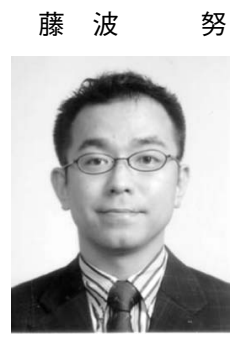

努（非会員） 1986 年早稲田大学第一文学部哲学 科卒業。同年，(株) 日立製作所システム開発研 究所入社。1995 年Center for Cognitive Science, University of Edinburgh 博士課程修了。 1995 年 Institutfuer Maschinelle Spracheverarbeitung, Universitaet Stuttgart 研究員。1998 年より北陸先端科学技術大学院大学・知識科学研 究科助教授。Ph.D. (Science and Engineering)。 この間, 知識工学, 自然言語意味論, 音声翻訳, 身体技能などの研究 に従事。情報処理学会, 言語処理学会各会員。

國 藤進 （非会員） 1974 年東京工業大学大学院理工学研

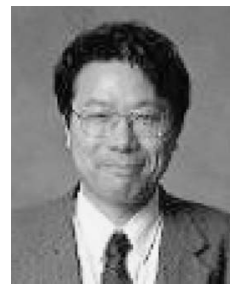
究科修士課程修了。同年, (株) 富士通国際情報 社会科学研究所入所。1982 1986 年, ICOT 出 向。1992 年より北陸先端科学技術大学院大学情 報科学研究科教授。1998 年より知識科学研究科教 授。現在では主として発想支援システム，グルー プウェア，知識システムの研究に従事。情報処理 学会創立 25 周年記念論文賞, 人工知能学会 1996 年度研究奨励賞各受賞。工学博士。情報処理学会, 計測自動制御学会, 電子情報通信学会, 日本創造学会等各会員。 